\title{
Effects of farmer social status and plant biocultural value on seed circulation networks in Vanuatu
}

\author{
Mathieu Thomas $^{1,2,3}$ and Sophie Caillon ${ }^{2,4}$
}

\begin{abstract}
Seed circulation among farmers, which is embedded in composite social networks, is a key process in the dynamics of seed systems that shape crop diversity. We analyzed the daily circulation of biological objects, i.e., cultivated plants (31 species, 284 landraces), within a community of first-generation migrants (16 households, 30 persons) living on the island of Vanua Lava in the South Pacific archipelago nation of Vanuatu. By combining participant observation, ethnobiological inventories, and social network analysis, we investigated how farmer social status and plant biocultural value affect plant circulation. Plant biocultural value was estimated by referring to their local classification according to uses, cultivation practices, growing environments, and biological properties. An aggregate plant circulation network (577 events) and three subnetworks (i.e., for starchy, side dish, or snack food categories) sharing the same 30 nodes were analyzed using exponential random graph models. Evidence that farmer social status influences the patterns of plant circulation was found through the distribution of structural parameters of the network, including: dyadic reciprocity; in-degree, out-degree, and their correlation; triadic cycling; and transitivity. At the scale of the aggregate network, direct or indirect reciprocity was not observed. Instead, a high out-degree (i.e., being a more frequent giver) and a negative correlation between in-degree and out-degree both confer prestige and reinforce hierarchy. These results suggest that some of the social dynamics of the Melanesian-type Big Man political system may persist, even though the system itself no longer exists in traditional form. Moreover, based on our comparative analysis of the three subnetworks, farmer social status appears to influence greatly the circulation of plants with high biocultural value while having little influence on plants with low biocultural value. Farmer social status and plant biocultural value (following their local classification) are important factors for understanding the social rules shaping seed circulation.
\end{abstract}

Key Words: emic categories; Exponential Random Graph Models; folk classification; food system; informal seed system; Oceania; seed exchange network; social network analysis

\section{INTRODUCTION}

Studying how tangible and intangible objects circulate among individuals can help in understanding human social relationships. Circulation of socially valued objects, exchanged primarily during ceremonies, has been studied extensively by social anthropologists. Examples from Oceania include the studies of Malinowski(1929), Dark (1974), Weiner (1992), Bonnemaison (1996a), Godelier (1996), and Stern (2013). However, few studies from Oceania have dealt with circulation of subsistence products (Monnerie 2014). This shortcoming must be surmounted because ceremonies cannot be organized without the everyday circulation of nonritualized objects (Monnerie 2012). Analyzing how nonprestigious objects such as food plants circulate in everyday life is also necessary to understand better the subsistence choices of farmers as they build up their set of crop plants in deciding how to face environmental and social changes.

Here, we examine the everyday circulation of propagules of cultivated plants within a community of farmers living on the island of Vanua Lava in the Pacific archipelago nation of Vanuatu. Propagules, or more simply, seeds (where "seed" is understood to include vegetative propagules, as well as true botanical seeds) are tangible, nonritualized, and alienable objects (i.e., capable of being transferred to someone else). Seed circulation (also called seed exchange) is one of the key processes in maintaining local crop diversity at both intra- and interspecific levels (Hodgkin et al. 2007, Thomas et al. 2011, Pautasso et al. 2013), thereby ensuring the evolutionary potential of agrosystems and contributing to their sustainability (Jarvis et al. 2011, Thomas et al. 2011, Leclerc and Coppens d'Eeckenbrugge 2012). Studying how seed circulation affects the dynamics of crop diversity is therefore crucial to understanding farmers' strategies for coping with global socioeconomic and environmental challenges such as climate change (Bellon et al. 2011).

Seed circulation has recently been studied by ethnobiologists, human geographers, and social anthropologists, specifically to depict plant-human relationships as sociocultural processes. Network representation was initially used to map seed circulation graphically (Emperaire and Peroni 2007, Demeulenaere et al. 2008, Abay et al. 2011). More recent papers have mobilized social network analysis to investigate the relations between network metrics and farmers' attributes through regression models (Poudel et al. 2015, Ricciardi 2015). Calvet-Mir et al. (2012b) and Reyes-García et al. (2013) focused on the link between the level of farmers' local ecological knowledge and their centrality within seed exchange networks in the context of Spanish home gardens. Kawa et al. (2013) showed, in three neighboring Amazonian caboclo communities, that farmers with the highest levels of plant diversity were not those who were most central within the seed exchange network. In these studies, circulation networks of seeds or plants were documented from an immaterial perspective because informants were only asked from whom they requested seeds. Very few studies have observed material circulation of seeds by asking the origin of each individual plant or each variety (Coomes and Ban 2004, Emperaire and Peroni 2007). Seed

${ }^{1}$ INRA, UMR 0320 / UMR 8120 Génétique Quantitative et Évolution, ${ }^{2}$ CNRS UMR 5175, Centre d'Écologie Fonctionnelle et Évolutive, ${ }^{3}$ CESAB/ FRB, ${ }^{4}$ Université de Montpellier - Université Paul-Valéry Montpellier - École Pratique des Hautes Études 
circulation described in this way is hence a physical realization of pre-existing social networks (Boster 1986, Badstue et al. 2006, McGuire 2008, Ellen and Platten 2011).

Accumulating a diversity of plants, either at the species or landrace level, is often associated with the quest for prestige (Heckler 2004, Caillon and Degeorges 2007, Muller 2009). Is this also true of the act of exchanging plants and their propagules? Researchers studying socially valued objects acknowledge that exchanges and reciprocity enhance the social prestige of those most active in exchange (Mauss 1925, Godelier 1996). Similar ideas about the importance of social status are found in sociology (Agneessens and Wittek 2012, Lazega et al. 2012). In social anthropology, the examples of the "kula ring" (Malinowski 1922, Weiner 1992) and the "Big Man" system (Sahlins 1965) in Melanesia are particularly famous and illustrative; in these systems, spending wealth is a strategy to gain or maintain prestige and power. Considering plant circulation as a social network, providing seeds could also contribute to enhancing and maintaining prestige (Heckler and Zent 2008, McGuire 2008, Coomes et al. 2015).

Going further in the description of plant circulation networks, Ellen and Platten (2011) showed that plant species and varieties follow distinct paths depending on their biological characteristics such as the way in which they are propagated (seeds vs. cuttings or tubers) or their capacity for storage and redistribution. However, a plant is more than just a biological object. Through its history, nomenclature, and uses, a plant carries memories from the past and provides cultural identity (Caillon and Degeorges 2007, Heckler and Zent 2008, Muller 2009, Leclerc and Coppens d'Eeckenbrugge 2012). Plants are thus defined as biocultural objects because farmers relate differently to them depending on their biological and sociocultural characteristics. Farmers define local categories of plants based on these biocultural characteristics, which mainly concern their uses, the agricultural practices applied to them, the agroecosystems where they are grown, and their biological forms (Meilleur 1998, Benz et al. 2007, Garine et al. 2013). Farmers also classify these local categories based on the biocultural value they accord to plants as an aspect of the local world view (Pollock 1992).

Following an approach combining participant observation with social network analysis, we assess two hypotheses about the sociocultural processes that shape plant circulation networks: the effects of farmer social status and the effects of plant biocultural characteristics on patterns in circulation networks. These two hypotheses were further divided into subhypotheses to investigate the effects they predict on network patterns.

\section{THEORETICAL FRAMEWORK}

\section{Effect of farmer social status on patterns of plant circulation networks}

\section{Plant circulation networks are not purely random}

The first step in analyzing the effect of farmer social status on plant circulation networks is to check that plants do not circulate at random. "At random" means that all pairs of farmers would have the same probability of being connected by a tie. This consideration is translated into subhypothesis 1a (Table 1, Fig. 1A).
Table 1. List of hypotheses and subhypotheses assessed.

\begin{tabular}{|c|c|}
\hline $\begin{array}{l}\text { Hypothesis } \\
\text { number }\end{array}$ & Hypothesis statement \\
\hline 1 & $\begin{array}{l}\text { Effect of farmer social status on patterns of plant } \\
\text { circulation networks }\end{array}$ \\
\hline 1a & $\begin{array}{l}\text { If plant circulation is not random, then arc effects are } \\
\text { expected to be significant. }\end{array}$ \\
\hline $1 b$ & $\begin{array}{l}\text { Reciprocity is expected in plant circulation. Reciprocal } \\
\text { dyadic ties (Fig. 1B) are expected to be over-represented } \\
\text { with respect to a random distribution. }\end{array}$ \\
\hline $1 \mathrm{c}$ & $\begin{array}{l}\text { If the quest for social prestige drives plant circulation, it } \\
\text { is expected that at the local-scale indirect reciprocity will } \\
\text { not be frequent. Triadic cycles should be under- } \\
\text { represented, and triadic transitivity over-represented, } \\
\text { with respect to a random distribution. }\end{array}$ \\
\hline $1 d$ & $\begin{array}{l}\text { If the quest for social prestige drives plant circulation, a } \\
\text { significant and positive out-degree effect is expected, i.e., } \\
\text { heterogeneity in the out-degree distribution, with a few } \\
\text { individuals having very high out-degree (nodal farmers) } \\
\text { and most others having lower out-degree. }\end{array}$ \\
\hline $1 \mathrm{e}$ & $\begin{array}{l}\text { A negative correlation is expected between in-degree and } \\
\text { out-degree of an individual. Indeed, to maintain expert } \\
\text { status, popular givers limit their requests to others for } \\
\text { plants. Conversely, a frequent receiver is rarely requested } \\
\text { to provide plants. }\end{array}$ \\
\hline 2 & $\begin{array}{l}\text { Effect of plant biocultural characteristics on patterns of } \\
\text { circulation networks }\end{array}$ \\
\hline $2 \mathrm{a}$ & $\begin{array}{l}\text { A significant positive out-degree, i.e., a few individuals } \\
\text { having very high out-degree and most others with lower } \\
\text { out-degree, is expected only in circulation networks of } \\
\text { the most socially valued categories of food plants. }\end{array}$ \\
\hline $2 b$ & $\begin{array}{l}\text { A frequent giver rarely receives plants from a frequent } \\
\text { receiver. Indeed, to maintain expert status, popular } \\
\text { givers do not request plants from frequent receivers. A } \\
\text { significant negative correlation between in-degree and } \\
\text { out-degree is expected only within circulation networks } \\
\text { of highly socially valued categories of food plants. }\end{array}$ \\
\hline
\end{tabular}

Absence of direct reciprocity: nonreciprocal dyads

Reciprocity is one of the most controversial topics within the theme of exchanges in anthropology. Mauss (1925) described the act of exchanging as the act of giving, receiving, and also repaying (Godelier 1996). The "spirit" of the gift or the "personality" of the object given creates a "spiritual" bond between the giver and the receiver. This bond constrains the recipient to make a countergift because the spirit of the object strives to return to its place of origin, and because the receiver will be struck by misfortune if no repayment is made. Thurnwald (1916) and Malinowski (1922) conceived reciprocity as a kind of juridical obligation that constitutes the basis for social relations; it represents a network of mutual services (Monnerie 2014). Receiving plants does not obligate the receiver to give back plants, but he or she can offer, with delay, counter-gifts of another nature such as prepared food, advice, or even labor. Reciprocity is one of the key values that has to be respected to assure the good functioning of societies (Gouldner 1960). Subhypothesis 1b is in line with the expectation of reciprocity (Table 1). 
Fig. 1. Endogenous patterns tested in the analysis of plant circulation networks (adapted from Robins et al. 2007).
Pattern

Name

Interpretation

(A)

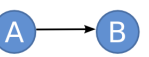

(B) $A \rightleftarrows B$

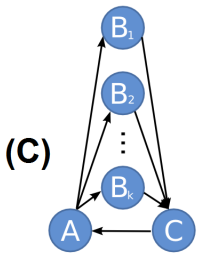

Alternating

Triangle Cycle

(D)
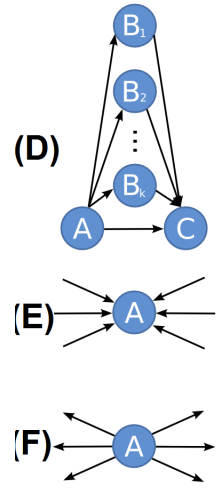

Arc

Reciprocity

Alternating

Triangle

Transitivity

Alternating

out-degree

Alternating

2-path

Transitivity

Density of the graph (intercept)

Tendency for direct reciprocity

Tendency for indirect reciprocity (triadic cycle)

Tendency to give to indirect receivers (triadic transitivity)

Alternating

Tendency to give to the main receivers

Tendency to request from the main givers

Correlation between in-degree and out-degree

Absence of indirect reciprocity: noncyclical triads

Generalized reciprocity refers to exchanges that are "putatively altruistic, transactions on the line of assistance given, and if possible and necessary, assistance returned. The ideal type here is Malinowski's 'pure gift' for which the expectation of reciprocity is infinite" (Sahlins 1965:147). Malinowski underlines the possible "intervention of a third person". When a receiver incurs a debt to a giver, he or she can repay it not only to the giver directly through reciprocal dyads, but also to another member of the group who is in debt to the giver. Such an arrangement corresponds to a "cyclical triad" or indirect reciprocity. Such behavior is unlikely from a social prestige perspective. For instance, giver A has no incentive in requesting plants from farmer $\mathrm{C}$ at the risk of losing the gain in reputation achieved by a gift of plants to farmer B (Fig. 1C). Thus, farmers with high local prestige can contribute to perpetuating their status by not requesting plants from indirect receivers of lower prestige than their own. In addition, the establishment of prestige is generally strengthened by a local hierarchical effect, with the propensity of the focal highstatus farmer A to give plants both to a lower-status farmer B and to an even lower status farmer $\mathrm{C}$, who also receives plants from farmer B (Fig. 1D). Rather than triadic cycles, triad transitivity, very different in its effect, is expected in plant circulation. Subhypothesis $1 \mathrm{c}$ is in line with this remark (Table 1).

\section{Popularity}

Nodal farmers who play a central role in knowledge circulation have been identified in the context of strategies to promote development (Lindstrom 1990, Davis and Wagner 2003, Isaac et al. 2007, Isaac 2012) and the management of agrobiodiversity (Smale and Bellon 1999, Brookfield et al. 2002, Subedi et al. 2005, Poudel et al. 2015, Ricciardi 2015). Using network descriptors such as degree-centrality, researchers have attempted to measure the popularity of farmers by their degree, i.e., the number of times an individual is mentioned as a seed exchange partner (CalvetMir et al. 2012a, Kawa et al. 2013, Reyes-García et al. 2013, Poudel et al. 2015, Ricciardi 2015). In the case of oriented networks, it is possible to distinguish between the centrality of individuals as receivers and as givers by examining in-degree and out-degree statistics, respectively. In-degree corresponds to the number of ties going to the focal individual (Fig. 1E), here, a receiver. Outdegree corresponds to the number of ties going out from the focal individual (Figs. 1E, F), here, a giver. Farmers with a high outdegree in the community have high popularity, reflecting their prestige as seed giver (nodal provider). Subhypothesis 1d was designed based on this statement (Table 1).

\section{Correlation between in-degree and out-degree}

Reputation could be built up at a local scale through dyadic and triadic relations and at a more global scale based on individuals' high out-degree. If the quest for status drives seed circulation, then patterns of circulation should obey rules of hierarchy. Therefore, it is not likely that high-status farmers with high outdegree will request plants from low-status farmers with high indegree, which is subhypothesis 1e (Fig. 1G, Table 1).

\section{Effect of plant biocultural characteristics on patterns in} circulation networks

Different crop species and landraces are not equally valued within communities (Haudricourt 1964, Bonnemaison 1991a, Caillon and Lanouguère-Bruneau 2005, Muller 2009, Caillon 2011, Garine et al. 2013). A value is assigned to an object through a complex combination of conscious and unconscious mental processes, relating to both functional and symbolic criteria and regarding both biological and sociocultural characteristics of the plant. For instance, food plants not only feed people, they are also associated with a social status and perceived as part of a mutual support system (Pollock 1992). It is difficult to disentangle the biocultural characteristics of plants into independent components. Local classification of food plants can be used to reflect these characteristics. Note that local classification (also called folk or emic classification) of food plants usually differs in many ways from the etic classification used by outside scientific observers.

Local classification, studied as a process, has been an important research topic for ethnobiologists for > 60 years (Berlin et al. 1974, Conklin 1974, Hunn 1982, Friedberg 1986, Ellen 1993). Following Ellen (2006), Alcántara-Salinas et al. (2013:2) define categories 
as, "those entities that the human mind creates in order to make sense of the diversity of experience, by grouping things, attributes and phenomena on the basis of similarity and difference." They define classification as, "the ways in which categories are related to each other, and the means by which particular cultural patterns are produced." Classifications have operational functions in the cognitive domain, mostly unconscious, such as ordering, storing, and locating knowledge. They also inform technical, metaphorical, and symbolic functions that serve as "a tool for the appropriation and socialization of nature" (Friedberg 1992:108). Higher level categories that include several species allow understanding of the way people perceive their environment because these categories are often complex, being defined by a diversity of types of knowledge (Bulmer 1970, Friedberg 1992). Although differences between higher and lower level categories have been studied frequently by ethnobiologists, how categories at the same level of classification vary in the way they are socially valued has rarely been investigated.

Such variation in social valuation of categories at the same level apparently occurs for food plants in the Pacific. Pollock (1992) showed that three categories are clearly distinguished: (1) starchy foods, particularly those provided by root and tree crops; (2) accompanying dishes; and (3) edible items (usually fruits) that rarely contribute to a meal. The last category is not perceived as "real food". A meal is considered complete if a cooked starchy food is associated with a raw or cooked accompanying dish (McCutcheon 1985 as cited in Pollock 1992). Pacific islanders have developed intimate relationships with their cultivated plants, especially the annual starch-rich root crops such as taro and yams, which are the crops most socially valued through ritual exchanges or ceremonies (Barrau 1958, Haudricourt 1964, Earle 1980, de Coppet 1981, Lemonnier 1982, Bonnemaison 1991b, 1996b, Di Piazza and Frimigacci 1991, Pollock 1992, Di Piazza 1999, Caillon and Lanouguère-Bruneau 2005, Coupaye 2009, Muller et al. 2010). Therefore, food plants are associated with different biocultural values, which are revealed by examining their local classification. Following the same idea, we assume that the less the social value accorded to the category of food plant, the less the circulation network is shaped by rules and socially constrained. Subhypotheses $2 \mathrm{a}$ and $2 \mathrm{~b}$ are derived to translate this general hypothesis into consequences for network patterns (Table 1).

\section{METHODS}

\section{Socioeconomic context}

Data were collected in Vanua Lava, a $330 \mathrm{~km}^{2}$ mountainous island situated in the northern part of Vanuatu, an archipelago in the South Pacific that acquired independence in 1980 (Fig. 2). Vanua Lava's 2623 inhabitants (VNSO 2009) are all independent farmers who produce, consume, and sell the products of their subsistence agriculture (mainly kava and copra). Men and women share both the main farming activities and local knowledge pertaining to agriculture.

The exogamous matrilineal society of Vanua Lava is divided into two moieties; a person is expected to marry a person from the other moiety. Although the typical Melanesian-type Big Man system of social status based on prestige described by Sahlins
(1965) no longer exists in its traditional form, its legacy is still visible in all types of contemporary relationships and exchanges. One is not born a Big Man, but rather becomes one by gaining respect from one's followers. A Big Man must exhibit skilled persuasion, knowledge, and wisdom to provide his followers with protection and economic assistance and to compete continuously with other potential Big Men by an ongoing process of reciprocity and redistribution of resources. The main principle can be summarized as "giving more brings greater prestige to the giver". Becoming a Big Man requires help provided by both men and women, who produce and give to the chosen person resources such as crops and pigs (Chowning 1979, Lepowsky 1990, Lutkehaus and Roscoe 1995).

Fig. 2. Location of Vanua Lava and the sampled households. Inset: Location of the Vanuatu archipelago.

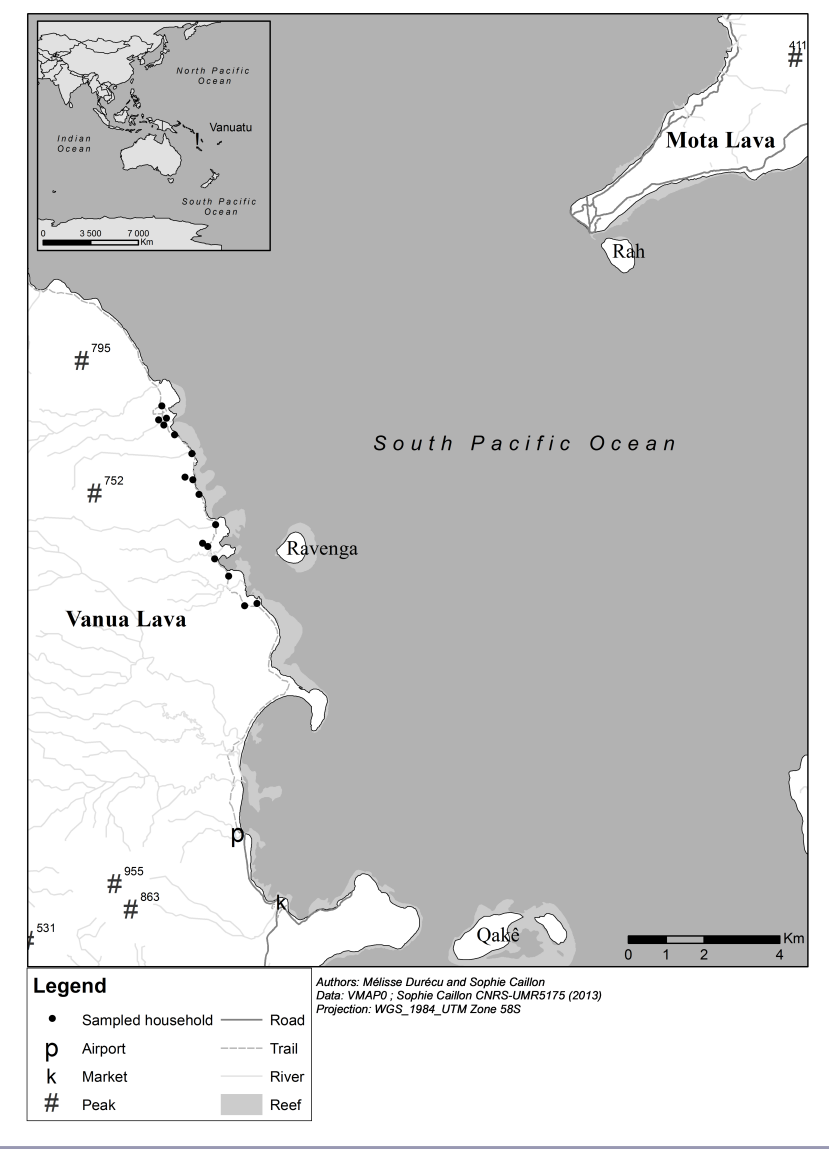

From 1978 to 1999, 16 family units (couples and children) migrated to Vanua Lava from a small and overpopulated island, Mota Lava, $12 \mathrm{~km}$ distant (Fig. 2). The first generation of migrants settled along a 10-km section of the east coast of Vanua Lava in 16 hamlets, each mainly composed of the migrant couple and their sons' families (i.e., virilocality). In view of the very short social and geographic distances between the two islands, migrants cannot be considered refugees and do not have to adapt to any large cultural, linguistic, or ecological differences. Their main 
motivation to migrate was to gain access to more land by recovering the land of their ancestors. Most migrants from Mota Lava are in fact the descendants of third- to fourth-generation ancestors who formerly lived on Vanua Lava. Four groups of migrants can be identified, corresponding to four apical ancestors (i.e., all members of one of these groups share the same common ancestor) from Vanua Lava. The local market where they sell their crops is a $2-4 \mathrm{~h}$ walk from their fields. The walk entails crossing mangrove swamps and large rivers. They maintain close relations with Mota Lava through trips back for regular weddings and sales of goods.

\section{Plant classification context}

The names of 254 local varieties (or landraces, belonging to 31 species) of plants grown for food were inventoried in the migrants' local language (Mwotlap) during preliminary ethnobiological fieldwork between 2007 and 2009. Participant observation and interviews revealed that each species belongs to one of three local categories based on uses and representations (Table 2): (1) starchy foods comprising mainly roots, tubers, and starchy fruits (11 annual species and one tree; 193 varieties); (2) side dish foods comprising vegetables and condiments (3 species, including perennial bushes and one tree; 26 varieties); and (3) snack foods, which are fruits and nuts ( 16 tree species; 35 varieties). Two species fit into two use categories, depending on the plant part or maturity. These were placed in the category in which they were most used, determined based on field observations.

The preliminary ethnographic study revealed that the value ascribed to plants differed among the three local categories. The starchy food category was by far the most valued. These foods must be cooked to be used; they are a main source of energy in the diet, and a meal must include them. They are described as being the "real food". When one invites people to eat, it is considered to be an insult to propose only side dish food or, even worse, only snack food. When a ceremony is organized, the first preoccupation is to produce starchy food in quantity. Moreover, farming practices associated with starchy food species are much more elaborate and valued; these crops are mainly grown in monoculture or in a separate space within the garden (Caillon 2012). Offering a complete meal requires that starchy food be served along with a side dish. Not doing so is called "eating dry" and is shameful, especially if a nonkin member is sharing the meal. Species that provide side dishes do not have a particular place within the agrosystem and are mainly grown in mixedspecies home gardens, close to houses. The least valued category is snack foods, which are mainly eaten by children. Species of this category are not considered part of a meal and are mainly consumed in gardens and outside meal periods. They are planted in all types of spaces, i.e., gardens, home gardens, agroforests, and along trails, wherever it is convenient.

\section{Data collection}

A mixed method approach was followed to understand the social organization, i.e., the nature of interactions between individuals and their relations to the world, which can be physical (i.e., ecosystem) or symbolic (i.e., cosmos; Domínguez and Hollstein 2014). We combined a participant observation approach with social network analysis.
Table 2. Description of plant species circulating among firstgeneration migrants to Vanua Lava.

\begin{tabular}{|c|c|c|}
\hline $\begin{array}{l}\text { Local classification } \\
\text { Species }\end{array}$ & $\begin{array}{l}\text { Number } \\
\text { of } \\
\text { varieties }\end{array}$ & $\begin{array}{c}\text { Number of } \\
\text { exchange } \\
\text { events }\end{array}$ \\
\hline \multicolumn{3}{|l|}{ Starchy food } \\
\hline Artocarpus altilis Farb. & 35 & 185 \\
\hline Dioscorea alata $\mathrm{L}$. & 34 & 282 \\
\hline Colocasia esculenta $\mathrm{L}$. & 34 & 273 \\
\hline Musa spp. & 26 & 252 \\
\hline Manihot esculenta Crantz & 16 & 124 \\
\hline Ipomoea batatas (L.) Lam. & 15 & 125 \\
\hline Dioscorea nummularia Lam. & 11 & 99 \\
\hline Xanthosoma sagittifolium (L.) & 7 & 65 \\
\hline Zea mays L. & 5 & 44 \\
\hline Alocasia macrorrhizos (L.) G. Don f. & 4 & 13 \\
\hline Dioscorea transversa $\mathrm{Br}$. & 3 & 27 \\
\hline Dioscorea bulbifera L. & 3 & 19 \\
\hline Total & 193 & 1508 \\
\hline \multicolumn{3}{|l|}{ Side dish food } \\
\hline Cocos nucifera $\mathrm{L}$. & 11 & 143 \\
\hline Bush cabbage $^{\dagger}$ & 9 & 50 \\
\hline Abelmoschus manihot (L.) Medik & 6 & 52 \\
\hline Total & 26 & 245 \\
\hline \multicolumn{3}{|l|}{ Snack food } \\
\hline Pometia pinnata Forster \& Forster f. & 6 & 25 \\
\hline $\begin{array}{l}\text { Canarium indicum L. or C. harveyi } \\
\text { Seeman }\end{array}$ & 5 & 39 \\
\hline Spondias cytherea Sonn. & 5 & 30 \\
\hline $\begin{array}{l}\text { Barringtonia edulis J. R. Forst. \& G. } \\
\text { Forst. }\end{array}$ & 4 & 47 \\
\hline Barringtonia sp. & 4 & 13 \\
\hline Mangifera indica $\mathrm{L}$. & 1 & 19 \\
\hline Citrus grandis (L.) Osbeck & 1 & 16 \\
\hline Citrus sinensis (L.) Osbeck & 1 & 16 \\
\hline Inocarpus fagifer (Parkinson) Fosberg & 1 & 14 \\
\hline Citrus limon (L.) Burm. F. & 1 & 13 \\
\hline Citrus reticulata Blanco & 1 & 13 \\
\hline Psidium guajava $\mathrm{L}$. & 1 & 13 \\
\hline Citrus $\times$ paradisi Macfad. & 1 & 12 \\
\hline $\begin{array}{l}\text { Syzygium malaccense (L.) Merr. \& } \\
\text { Perry }\end{array}$ & 1 & 11 \\
\hline Dracontomelon sinense Stapf & 1 & 8 \\
\hline Persea americana Miller & 1 & 7 \\
\hline Total & 35 & 296 \\
\hline
\end{tabular}

This category includes nine different local names, probably corresponding to nine distinct species. Only two species were identified by botanist P. Heuret: Gratophilum pictum (L.) Griff. and Polyscias fruticosa (L.) Harms.

Our study focused on plant circulation among the 16 households of the first generation of migrants in Vanua Lava. Information on the migration history, geographical localization, gender, age, land rights, and genealogical position was collected for 30 adults (14 couples and two widows) belonging to the 16 households through simultaneous interviews of the husband and wife. In addition, for each of the 254 landraces, farmers were asked (1) whether they had already cultivated it, and if so, (2) who had first received it in the household, and (3) who gave it to that person. We only asked about plants received, and not plants given, because people find it is much more difficult to remember the numerous 
acts of giving compared to acts of receiving, each of which is testified to by the plants growing (or that had formerly grown) in their gardens. Because the migration was a relatively recent event, we made the assumption that additional plant circulation events following the original acquisition and transmission events were negligible. This assumption was supported by the fact that farmers rarely mentioned such cases spontaneously during surveys. Events of plant acquisition documented during the survey summarize a two-way process: (1) an oral request from the informant to his or her plant provider, and (2) a physical transfer of plants from the provider to the informant. Thus, denied requests were not reported. However, norms concerning circulation among Vanuatu farmers incite people to provide plants whenever they are solicited. Simultaneously, individuals must choose from whom and how often they will request seeds to avoid being too indebted (Caillon 2012). A total of 2049 events were recorded. Of these, $47 \%$ were exchanges among the firstgeneration migrants, and 53\% concerned plants coming from external sources: from the island of origin, Mota Lava $(23 \%)$; from the forest on Vanua Lava (16\%); from the agronomic research station based on Espiritu Santo Island (7\%), $180 \mathrm{~km}$ to the south; from the local Vanua Lavans (5\%); and from other islands $(2 \%)$.

\section{Network visualization}

Network visualization provides informative representations of many types of actor relationships. In the case of plant circulation networks, each node represents a farmer, and an oriented tie from one farmer (i) to another (j) indicates that farmer i provides one or more landraces to $\mathrm{j}$. All the plant circulation events recorded during interviews of first-generation migrants were represented in an aggregate network. Then, events were separated into three groups according to the category of plant involved in the circulation event (starchy food, side dish, or snack foods), allowing us to plot three subnetworks. Networks were represented using igraph version 0.6.6 (Csardi and Nepusz 2006), a package developed in R v3.1.2 (R Core Team 2014).

\section{Model specification}

In this paper, we propose to go further than a simple representation of networks by using probabilistic models called exponential random graph models (ERGMs), which were specifically developed for social network analysis (Snijders et al. 2006). To our knowledge, these models have not yet been applied to plant circulation networks. From our data, we estimate an ERGM to test assumptions about processes shaping the distribution of ties within the different plant circulation networks. Models of the ERGM family are probabilistic models that consider each tie as a random variable and can represent a variety of structural tendencies (reciprocity, transitivity, etc.) that define complicated dependence patterns (Robins et al. 2007). In addition to "self-organized" social processes, it is possible to account for selection processes (homophily, heterophily, assortativity, etc.) that are affected by attributes of nodes.

As previously mentioned, our interviews focused on all the events by which each crop species or landrace was first acquired for the complete set of 30 first-generation migrants who settled on the island of Vanua Lava. ERGMs work with closed networks, i.e., the complete set of actors involved in the investigated process and the complete set of ties that exists among this set of actors. To fulfill the conditions for applying an ERGM, we defined the boundary of our data set considering only plant circulation among the first-generation migrants $(28 \%$ of the total number of plant circulation events, 577 circulation events of the 2049 inventoried in total). Indeed, $53 \%$ of the plant source events came from outside the group of first-generation migrants and had to be excluded. Because these events represent a large proportion of plant circulation, this information was partially and indirectly accounted for in the ERGM by defining a continuous covariate, called external in-degree (Fig. 3). For the remaining events (19\%), information was available only at the household level, i.e., it was not possible to distinguish which person of the household, the man, the woman, or a child, provided or received the plant. For this reason, such circulation events were considered as missing data and were not used in the ERGM.

Fig. 3. Exogenous patterns tested in the analysis of plant circulation networks.

\begin{tabular}{|c|c|c|}
\hline Pattern & Name & Interpretation \\
\hline (A) & $\begin{array}{l}\text { Weighted external } \\
\text { in-degree sender }\end{array}$ & $\begin{array}{l}\text { Tendency to give } \\
\text { when you received } \\
\text { from outside }\end{array}$ \\
\hline (B) & $\begin{array}{l}\text { Weighted external } \\
\text { in-degree receiver }\end{array}$ & $\begin{array}{l}\text { Tendency to receive } \\
\text { when you received } \\
\text { from outside }\end{array}$ \\
\hline (C) & $\begin{array}{l}\text { Weighted external } \\
\text { in-degree homophily }\end{array}$ & $\begin{array}{l}\text { Tendency to give to } \\
\text { similar persons in } \\
\text { terms of outside } \\
\text { behaviour }\end{array}$ \\
\hline
\end{tabular}

Following the theoretical framework introduced in the previous section, different endogenous patterns were specified following the ERGM specification procedure introduced by Snijders et al. (2006). Arc can be seen as the equivalent of the intercept in a regression model (1a in Table 1, Fig. 1A) and can be used to test for the randomness of the network. Reciprocity was included in the model to test the hypothesis of absence of direct reciprocity in plant circulation networks (1b in Table 1, Fig. 1B). Including alternating-triangle cycle and alternating-triangle transitivity in our model allowed us to assess subhypothesis 1c (Table 1), which postulates the absence of indirect reciprocity and of cyclical triads (Figs. 1C, D, respectively). Alternating in-degree and alternating out-degree were included to test the hypothesis that certain givers are popular in plant circulation (1e in Table 1, Figs. 1E, F, respectively). The correlation between in-degree and out-degree was assessed using the alternating-two-path effect to test subhypothesis 1e (Table 1).

Additional covariates of nodes were also included in the model to control for selection processes such as homophily, heterophily, and giver or receiver effects. We tested, for example, whether the gender of the giver or receiver of plants affects out-degree or indegree, respectively, of the individual. We also tested for the gender homophily effect, which assesses whether individuals tend to exchange plants preferentially with other individuals of the same gender, and the gender heterophily effect, which assesses 
whether the opposite pattern holds. These effects were tested with gender and with external in-degree (Fig. 3). Household membership was included as a covariate of ties to test whether people from the same household are more likely to circulate plants among themselves than with people outside the household. Because the gender and household membership covariates were never significant, they were removed from the final model.

An ERGM was first performed on the aggregate network to test subhypotheses 1a-d. ERGMs were then performed independently for each of the three subnetworks (starchy food, side dish, and snack food) to test subhypotheses $2 \mathrm{a}$ and $2 \mathrm{~b}$. Estimations were performed using a Markov Chain Monte Carlo algorithm implemented in PNET software (Wang et al. 2009). Goodnessof-fit criteria were verified for each model following the procedure of Koskinen and Snijders (2012).

\section{RESULTS}

\section{Descriptive analysis}

The aggregate plant circulation network showed a relatively high density ( $d=0.19$; Fig. 4 ) compared to the circulation networks obtained for each of the three local plant food categories. Of the latter, the subnetwork for starchy foods showed the highest density $(d=0.16)$, whereas densities were substantially lower for both the subnetwork for side dish foods $(d=0.04)$ and that for snack foods $(d=0.06$; Fig. 5). These differences in density were consistent with the total number of events per category: 1418 events for starchy foods, 235 for side dish foods, and 293 for snack food plants. There was also a higher average number of circulation events per species for the starchy food category (118.2 events/species) compared to the side dish food and snack food categories (78.3 and 18.3 events/ species, respectively). These descriptive results confirm that, following migration, starchy food plants circulated more than plants of the two other categories.

Fig. 4. Aggregate plant circulation network (density $=0.19)$. Women are represented by circles and men by squares. Node size is proportional to the total degree (in-degree plus outdegree).

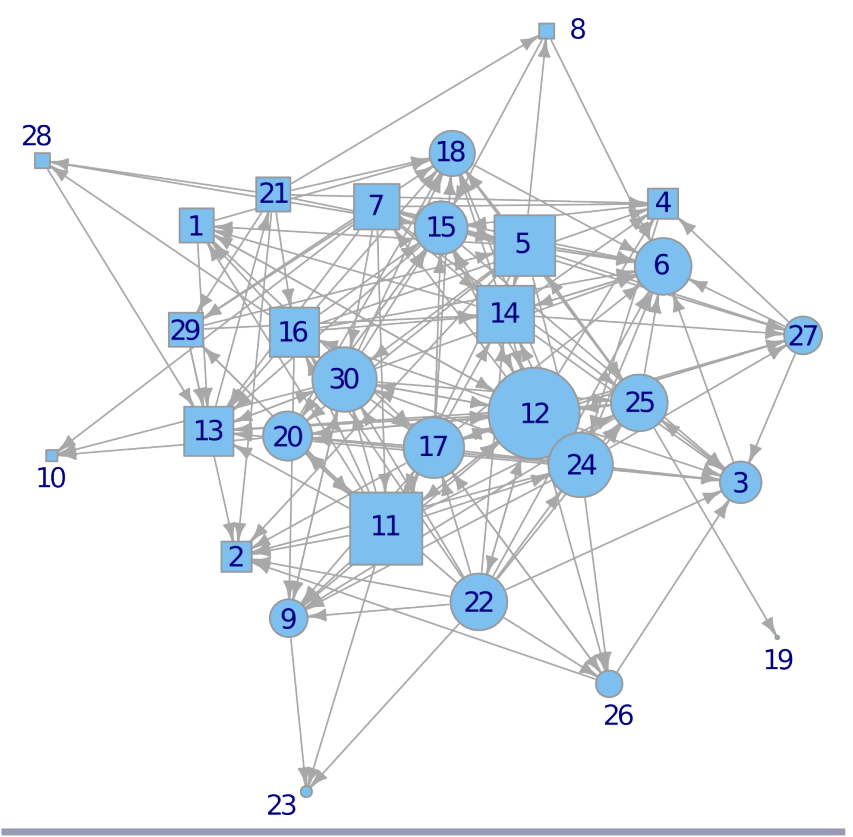

Fig. 5. Plant circulation subnetworks. (A) Starchy foods (density $=0.16)$. (B) Side dish foods (density $=0.04)$. (C) Snack foods (density $=0.06$ ). Women are represented by circles and men by squares. Node size is proportional to the total degree (in-degree plus out-degree).
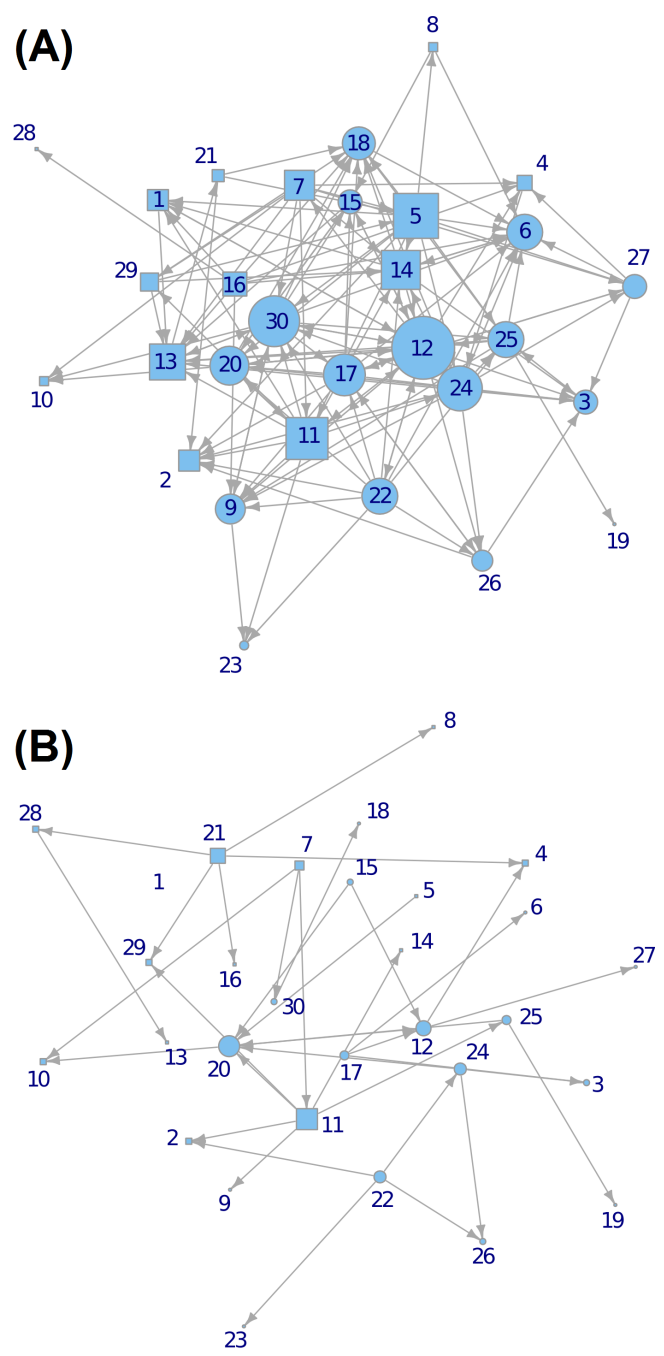

(C)

8

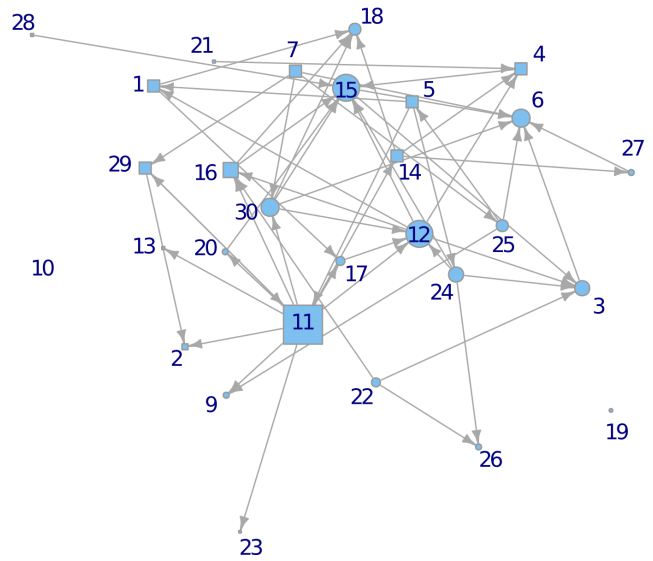


Table 3. Estimations of exponential random graph models (SE) for circulation networks for: all food plants (aggregate), starchy foods, side dish foods, and snack foods.

\begin{tabular}{|c|c|c|c|c|c|}
\hline \multirow[b]{2}{*}{ Factor } & \multirow[b]{2}{*}{ Effect } & \multicolumn{4}{|c|}{ Circulation network } \\
\hline & & Aggregate & Starchy foods & Side dish foods & Snack foods \\
\hline \multirow[t]{7}{*}{ Endogenous } & Arc & $-3.519(1.075)^{*}$ & $-4.522(0.874)^{*}$ & $-3.506(0.752)^{*}$ & $-4.821(0.664)^{*}$ \\
\hline & Reciprocity & $-0.392(0.377)$ & $-0.146(0.41)$ & $-3.517(14.928)$ & $-0.703(1.084)$ \\
\hline & In-degree & $0.342(0.403)$ & $0.613(0.343)$ & $-0.537(0.503)$ & $0.624(0.335)$ \\
\hline & Out-degree & $0.774(0.323)^{*}$ & $0.999(0.301)^{*}$ & $1.076(0.311)^{*}$ & $0.507(0.361)$ \\
\hline & Triadic transitivity & $0.286(0.166)$ & $0.237(0.173)$ & $0.156(0.658)$ & $0.057(0.356)$ \\
\hline & Triadic cycling & $0.113(0.084)$ & $0.034(0.102)$ & $-1.841(7.48)$ & $-0.253(0.354)$ \\
\hline & Two-path & $-0.195(0.049)^{*}$ & $-0.132(0.057)^{*}$ & $-0.03(0.167)$ & $-0.004(0.104)$ \\
\hline \multirow[t]{3}{*}{ Exogenous } & External in-degree giver & $0.01(0.003)^{*}$ & $0.013(0.003)^{*}$ & $0.096(0.042)^{*}$ & $0.079(0.026)^{*}$ \\
\hline & External in-degree receiver & $0.006(0.003)^{*}$ & $0.009(0.004)^{*}$ & $-0.087(0.053)$ & $0.027(0.022)$ \\
\hline & External in-degree heterophily & $-0.008(0.003)^{*}$ & $-0.013(0.005)^{*}$ & $-0.087(0.049)$ & $-0.009(0.024)$ \\
\hline
\end{tabular}

$* P<0.05$

\section{Exponential random graph model of the aggregate plant circulation network}

\section{Exogenous factors}

Exogenous factors were control variables in our model because we focused on endogenous effects. Significant effects were associated with having received, or not received, plants from sources outside the community of first migrants (i.e., external in-degree of givers and receivers in Table 3). Significant positive giver and receiver effects for external in-degree indicated a tendency for farmers who received more seeds from outside to provide more plants to others and receive more plants from others. In addition, a significant negative heterophily effect (i.e., positive homophily) for external in-degree indicated that farmers tended to request plants from other farmers who were similar to them in terms of the way they acquired plants from outside the community of first migrants. As already noted, gender homophily and giver and receiver effects were never significant (data not shown). Being a man or woman did not affect the way in which one acquired or received food plants.

\section{Endogenous factors}

A significant effect of arc confirmed that ties were not randomly distributed, justifying the use of relatively complex statistical models such as ERGMs (Table 3). The absence of a significant reciprocity effect indicated that there was no trend for over- or under-representation of direct reciprocity in the plant circulation networks we studied. The lack of a significant alternating in-degree effect indicated that different farmers tended to receive plants from the same average number of providers. Positive alternating outdegree showed a tendency for popularity, with a few actors having a higher probability than others of being requested to provide plants. Significant negative alternating two-path highlighted the negative correlation between in-degree and out-degree, with a tendency for the low in-degree farmers to seek plants from high out-degree farmers. Neither triadic transitivity nor triadic cycling were significant, showing the absence of a tendency for triadic closure.

\section{Exponential random graph models of plant circulation subnetworks}

\section{Exogenous factors}

External in-degree was significant for all three subnetworks, showing the same effect of a few farmers receiving plants from outside, independently of the local category (Table 3 ). In contrast to networks for the side dish and snack food categories, a significant positive external in-degree receiver effect was detected for the starchy food network. This means that farmers with a high external in-degree were simultaneously more likely to give and receive plants among migrants of the first generation. Negative and significant heterophily (i.e., positive homophily) was observed for the starchy food network, similarly to the aggregate plant circulation network.

\section{Endogenous factors}

The effect of arc was negative and significant for the three subnetworks, confirming the complex distribution of ties observed at the aggregate level (Table 3). Reciprocity was not significant for any of the three networks, a result consistent with that obtained at the aggregate level. Positive significant alternating out-degree was observed for starchy foods and side dish foods, but not for snack foods. This difference revealed considerable variation in the popularity of givers for the first two categories. Concerning the triadic effects, a negative and significant alternating two-path effect was only observed for the starchy food category.

\section{DISCUSSION}

\section{Specificities of plant circulation networks}

The structure of the aggregate plant circulation network showed neither over- nor under-representation of reciprocity, both direct and indirect. Subhypotheses $1 \mathrm{~b}$ and $1 \mathrm{c}$ (Table 1) were therefore not validated. Concerning direct reciprocity ( $1 \mathrm{~b}$ in Table 1$)$, it could be considered that our interview methodology, which focused on only the first source of each plant, may have missed acts of delayed reciprocity. However, according to farmer discourse and our long-term observations, such events are too rare to modify the observed pattern. More importantly, the circulation events we described corresponded to a subset of the tangible and intangible objects that circulate daily within the community (multiplex network of circulating objects). In this Melanesian-type system, receiving plants does not force the receiver to give back plants, but he or she can offer, with delay, counter-gifts of another nature such as prepared food, advice, or even labor (Malinowski 1929, Weiner 1992, Godelier 1996, Caillon 2012). This multiplex reciprocity is one of the key values that must be respected to assure the good functioning of societies. 
Unfortunately, our sampling design was limited to only one class of artifacts and was thus not adapted to test whether reciprocity was often fulfilled by repaying an object of a different nature.

Another expectation following the social prestige paradigm was an over-representation of cyclical triadic structures, which would reveal the hierarchy associated with prestige (1c in Table 1). This hypothesis was not validated. We thus found no influence of social prestige on the patterns of plant circulation for specific relations (dyadic and triadic levels). Nevertheless, our results show significant overdispersion of out-degrees (1d in Table 1) and a significant negative correlation between in-degree and out-degree for the same individual (1e in Table 1). A subset of farmers is particularly popular in giving plants and is not disposed to request plants from those who received these gifts. This plant-giving behavior generates generalized prestige, and this finding is consistent with the notion that striving for status (Sorokin 1927, Agneessens and Wittek 2012) may be a driver of seed circulation patterns. However, from this perspective, we should also have observed an over-representation of nonreciprocal dyads and noncyclical triadic structure (Agneessens and Wittek 2012, Lazega et al. 2012), which was not the case. Although the Big Man political system is no longer physically present in its traditional form, its legacy, in the form of the spirit of the foundations and rules, seems still to influence patterns of plant circulation in networks today. The constant renewal of the debt relationship through disequilibrium between givers and receivers allows maintenance of both the prestige and popularity of the givers. This self-organized unstable state allows the coherence of society. When giving plants, one should not then request plants from someone considered to be of lower status, who can be either a person to whom the giver has given plants or a person who has the reputation of frequently requesting plants. To build up one's prestige and to expect a bigger delayed repayment, farmers have to find plants from even bigger givers within the community. It is possible to characterize these popular givers of plants on Vanua Lava.

The first-generation migrants moved to Vanua Lava to recover their lands. Of the 30 first-generation migrants, 17 were able to retrace a family tree as proof of their legitimacy on this territory; most of this information was shared and validated by migrants. This group of people showed an average out-degree of 8.3. Of these 17 individuals, 11 were particularly active in collective tasks and showed an average out-degree of 10.9 (Fig. 4, individuals 5, $7,11,12,16,17,21,22,24,25$, and 30$)$. The six other individuals (Fig. 4, individuals 1, 9, 10, 15, 27, and 29) who also claimed to descend from an ancestor from Vanua Lava, but who were more discreet (e.g., not involved in community activities) and migrated later on, showed an average out-degree of 3.6. The remaining 13 who cannot specifically claim to have an ancestor showed an even lower out-degree, with an average of 2.6. These last individuals had gained the right to settle through services they gave in the past or through their ability to argue convincingly to have kinship relations with distant relatives. It must be emphasized that for the local inhabitants of Vanua Lava, migrants must fulfill other conditions in addition to a simple genealogical tree showing kin relations: they should have participated in every death ceremony of their clan on Vanua Lava; they must demonstrate how much they know about their territory (i.e., be able to name the different places and to define their territory by reference to specific geosymbols such as trees or stones); and they must remember their matriclan. Because all the migrants (and the inhabitants of their former island) had forgotten their matriclans, few individuals chose to be adopted or to marry their son to a local inhabitant from Vanua Lava. To summarize, the only legitimate migrants, from a Vanua Lavan perspective, are individuals 5, 11, 25 , and 29, who have an average out-degree of 10 .

The age of household members, which is related to the order of migration, is also a factor that can partially explain the popularity of certain givers, as already suggested in the literature (Ban and Coomes 2004, Alvarez et al. 2005, Perrault-Archambault and Coomes 2008, Meinzen-Dick and Eyzaguirre 2009). The 11 farmers with the highest out-degree all migrated to Vanua Lava before 1984, with the exception of one woman (farmer 12), who happens to be married to a government agricultural officer and therefore has access to uncommon species and landraces. Migrants who have settled for a longer time are more likely to have accumulated species and landraces that are better adapted to their new home. The climate on Mota Lava is drier, and thus the plants that migrants brought with them may not all have been suited to Vanua Lava's climate and soils. Nonetheless, unexpectedly, no correlation was found between out-degree and crop diversity (data not shown), similar to the results reported by Kawa et al. (2013). These findings differ from those of other published studies that show a positive correlation between centrality and crop diversity (Ban and Coomes 2004, Calvet-Mir et al. 2012a). The pattern observed among Vanua Lava farmers could be explained by the specific context of migration, wherein farmers develop survival strategies soon after arrival in their new location. For example, newly arrived farmers may test numerous plants for their suitability for wet climatic conditions, leading to a relatively high level of crop diversity grown per farmer. Another possible explanation for the absence of a positive correlation between crop diversity and farmer centrality is that having a few bioculturally valued varieties of a crop can be more important than having a large number of varieties. In other words, the quality of varieties managed by experts might be more important than the number of varieties they manage. To summarize, to become a prestigious plant giver, one must secure land rights, be one of the oldest migrants, and thus have the reputation of cultivating plants that are more adapted to the new conditions or that are rare because they are exotic.

Moreover, the significant effects of external in-degree of giver and receiver (Fig. 3, Table 3) indicate that farmers who receive plants from outside the community of the first-generation migrants (i.e., from their island of origin, the nearby forest [in which are found old fallows], the agronomic research station, and local inhabitants of Vanua Lava or of other islands) give and receive more plants than the others. As shown by the external indegree homophily, farmers with easy access to outside sources tend to give plants to other farmers with a similar profile. Nevertheless, we acknowledge that in our statistical design, the external in-degree is a control variable that is difficult to interpret. In addition, the absence of an effect of gender (homophily, giver and receiver) is consistent with the fact that men and women on Vanua Lava share most farming activities and agricultural knowledge. 
Effect of plant local categories on plant circulation subnetworks ERGMs for the plant circulation subnetworks reveal differences among the subnetworks in the significance of parameters in explaining structural patterns. The correlation between in- and out-degree is significant only for starchy food plants. Out-degree is significant for starchy foods and side dish foods, and no degree parameter is significant for the snack food plant circulation network. These results indicate that the circulation network for starchy foods is more constrained compared to the networks for side dish and snack foods. This could be interpreted as a relaxation of exchange rules for the latter two networks. These differences are consistent with subhypotheses $2 \mathrm{a}$ and $2 \mathrm{~b}$ (Table 1). Social status within a group of farmers is revealed by different kinds of expertise: the level of knowledge for different facets of technical know-how, but also the level of crop diversity maintained. Accumulating rare landraces of highly valued species is a better strategy to strengthen prestige than is cultivating landraces of less-valued species of side dish and snack foods. To maintain their status, people should avoid asking for highly valued landraces from people they consider having a lower social status than themselves. Such a phenomenon was not observed for less-valued species because these do not affect the social status of farmers. In addition, no gender effect was detected for the different plant categories, consistent with the sharing of labor in farming tasks on Vanua Lava.

Here, we analyzed the circulation network for each local category of plants as an independent network. Further investigations are necessary to improve the model used for one plant category, for example, by declaring the two other networks as covariates of the model. Another alternative could be to use a bivariate ERGM to estimate the level of interaction between two networks through the entrainment effect (Huitsing et al. 2012). To explore further how plant circulation is embedded within other social networks, it would be relevant to study, simultaneously and in interaction, the circulation of objects of different natures (e.g., musical instruments or other artifacts) and different networks of relationships in which these objects may circulate (kinship, advice, neighbor, and friendship networks), all in a multiplex analysis.

\section{CONCLUSION}

We investigated the properties of plant circulation networks on the island of Vanua Lava by combining participant observation with statistical modeling. We showed that social prestige seems to play a role in structuring plant circulation networks in Vanuatu society. Our findings suggest that some elements of the Melanesian-type Big Man political system, although no longer in its traditional form, may still influence how people engage in exchange. The system confers prestige to the biggest givers (high outdegree) and reinforces hierarchy. Food plants, as alienable, material, and nonritualized objects, are appropriate indicators to reveal social rules that are involved in circulation networks within a community. However, they constitute only one piece of the puzzle because counter-gifts can be of a different nature.

In addition, we showed that the influence of farmers' social status is particularly important for plants to which high biocultural value is ascribed, and is negligible for plants of low biocultural value. These results strengthen the conclusion that crop diversity is not randomly distributed in space and that social organization, especially the differences in terms of social status of the farmers and of biocultural value of plants, strongly shape the distribution of plant diversity by affecting how plants circulate among farmers. These findings provide elements that can help in disentangling the effects of biological and sociocultural properties of plants on the dynamics of crop diversity.

The richness of our results confirms that social network analysis, ERGM in particular, is a promising approach to answering anthropological questions, even if the constraint of having to work with a system that is considered closed is a major challenge, methodologically and conceptually, because some plant circulation events come from outside the targeted population and cannot be accounted for directly in the statistical model. This mixed method approach could help anthropologists to formalize and test their research questions and to mobilize their fieldwork data to do so. Facing such a challenge implies integrating the richness and diversity of anthropological knowledge on themes ranging from ecology to the society's cosmology. It is also important to undertake long-term surveys with collection of diachronic or longitudinal data because social processes are fundamentally dynamic. We think that methods recently developed in social network analysis, emphasizing dynamic analyses, can enable researchers to overcome these challenges and thus significantly improve the understanding of the characteristics of plant circulation networks.

Responses to this article can be read online at: http://www.ecologyandsociety.org/issues/responses. $\mathrm{php} / 8378$

\section{Acknowledgments:}

We gratefully acknowledge the French Fondation pour la Recherche sur la Biodiversité (FRB), which made possible NetSeed, an international collaboration of researchers studying farmer seed networks. Mathieu Thomas was provided with a six-month postdoctoral fellowship within this program. The Centre de Synthèse et d'Analyse sur la Biodiversité (CESAB) provided essential logistical support for regular workshops on the subject, which enabled us to develop and mature both the theoretical and methodological aspects of our research. Additional support of the ongoing research collaboration through the MIRES and MADRES networks was provided by the following agencies: the Réseau National des Systèmes Complexes (RNSC), the Institut National de la Recherche Agronomique (INRA), and the Centre National de la Recherche Scientifique (CNRS). We thank the Scientific Council of the University of Montpellier for funding the fieldwork, and the Vanuatu Kultural Senta (VKS) for providing information and organizational facilities. We are grateful to Mélisse Durecu for the cartographic work, and to Doyle McKey, Denis Monnerie, and three anonymous reviewers for their proofreading and advice. This research would not have been possible without the generosity of many farmers from the east coast of Vanua Lava, in particular, the hospitality of Edwin Tagar and May Danasé. This article is dedicated to their recently deceased son, Ken. 


\section{LITERATURE CITED}

Abay, F., W. de Boef, and Å. Bjørnstad. 2011. Network analysis of barley seed flows in Tigray, Ethiopia: supporting the design of strategies that contribute to on-farm management of plant genetic resources. Plant Genetic Resources 9(4):495-505. http://dx.doi. org/10.1017/S1479262111000773

Agneessens, F., and R. Wittek. 2012. Where do intraorganizational advice relations come from? The role of informal status and social capital in social exchange. Social Networks 34 (3):333-345. http://dx.doi.org/10.1016/j.socnet.2011.04.002

Alcántara-Salinas, G., R. F. Ellen, L. Valiñas-Coalla, J. Caballero, and A. Argueta-Villamar. 2013. Alternative ways of representing Zapotec and Cuicatec folk classification of birds: a multidimensional model and its implications for culturallyinformed conservation in Oaxaca, México. Journal of Ethnobiology and Ethnomedicine 9(1):81. http://dx.doi. org/10.1186/1746-4269-9-81

Alvarez, N., E. Garine, C. Khasah, E. Dounias, M. HossaertMcKey, and D. McKey. 2005. Farmers' practices, metapopulation dynamics, and conservation of agricultural biodiversity on-farm: a case study of sorghum among the Duupa in sub-Sahelian Cameroon. Biological Conservation 121(4):533-543. http://dx.doi. org/10.1016/j.biocon.2004.05.021

Badstue, L. B., M. R. Bellon, J. Berthaud, X. Juárez, I. M. Rosas, A. M. Solano, and A. Ramírez. 2006. Examining the role of collective action in an informal seed system: a case study from the central valleys of Oaxaca, Mexico. Human Ecology 34(2):249-273. http://dx.doi.org/10.1007/s10745-006-9016-2

Ban, N., and O. T. Coomes. 2004. Home gardens in Amazonian Peru: diversity and exchange of planting material. Geographical Review 94(3):348-367. http://dx.doi.org/10.1111/j.1931-0846.2004. $\underline{\mathrm{tb} 00177 . \mathrm{x}}$

Barrau, J. 1958. Subsistence agriculture in Melanesia. Bernice P. Bishop Museum Bulletin 219. Bernice P. Bishop Museum, Honolulu, Hawaii.

Bellon, M. R., D. Hodson, and J. Hellin. 2011. Assessing the vulnerability of traditional maize seed systems in Mexico to climate change. Proceedings of the National Academy of Sciences 108(33):13432-13437. http://dx.doi.org/10.1073/pnas.1103373108

Benz, B., H. Perales, and S. Brush. 2007. Tzeltal and Tzotzil farmer knowledge and maize diversity in Chiapas, Mexico. Current Anthropology 48(2):289-300. http://dx.doi.org/10.1086/512986

Berlin, B., D. E. Breedlove, and P. H. Raven. 1974. Principles of Tzeltal plant classification: an introduction to the botanical ethnography of a Mayan-speaking people of highland Chiapas. Academic Press, New York, New York, USA.

Bonnemaison, J. 1991a. Magic gardens in Tanna. Pacific Studies 14(4):71-89. [online] URL: https://ojs.lib.byu.edu/spc/index.php/ PacificStudies/article/view/30707/29166

Bonnemaison, J. 1991b. Le taro-roi: une horticulture d'abondance dans l'Archipel du Vanuatu (Mélanésie). Pages 305-315 in R. Blanadet, J. M. Amat-Roze, S. Guichard-Anguis, C. Balaize, and A. Louchet, editors. Aspects du monde tropical et asiatique: hommage à Jean Delvert. Presses de l'Université de ParisSorbonne, Paris, France.
Bonnemaison, J. 1996a. Gens de pirogue et gens de la terre. Editions de l'ORSTOM, Paris, France.

Bonnemaison, J. 1996b. Gens du taro et gens de l'igname. Pages 389-404 in M. Julien, M. Orliac, and C. Orliac, editors. Mémoire de pierre, mémoire d'homme: tradition et archéologie en Océanie: hommage à José Garanger. Publications de la Sorbonne, Paris, France.

Boster, J. S. 1986. Exchange of varieties and information between Aguaruna manioc cultivators. American Anthropologist 88 (2):428-436. http://dx.doi.org/10.1525/aa.1986.88.2.02a00100

Brookfield, H., C. Padoch, H. Parsons, and M. Stocking. 2002. Cultivating biodiversity: understanding, analysing and using agricultural diversity. ITDG Publishing, London, UK. http://dx. doi.org/10.3362/9781780441092

Bulmer, R. 1970. Which came first, the chicken or the egg-head? in J. Pouillon and P. Maranda, editors. Echanges et communications: mélanges offerts à Claude Lévi-Strauss. Mouton, The Hague, The Netherlands.

Caillon, S. 2011. Ethnobotanique du cocotier (Cocos nucifera L.) sur l'île de Vanua Lava (Vanuatu). Journal de la Société des Océanistes 133:333-352.

Caillon, S. 2012. Produce to exchange. The taro water-gardens on Vanua Lava (Vanuatu), a social and sustainable place. Pages 189-208 in M. Spriggs, D. Addison, and P. J. Matthews, editors. Irrigated taro (Colocasia esculenta) in the Indo-Pacific: biological, social and historical perspectives. Senri Ethnological Series 78. National Museum of Ethnology, Osaka, Japon.

Caillon, S., and P. Degeorges. 2007. Biodiversity: negotiating the border between nature and culture. Biodiversity and Conservation 16(10):2919-2931. http://dx.doi.org/10.1007/s10531-007-9149-7

Caillon, S., and V. Lanouguère-Bruneau. 2005. Gestion de l'agrobiodiversité dans un village de Vanua Lava (Vanuatu): stratégies de sélection et enjeux sociaux. Journal de la Société des Océanistes 120-121(1):129-148. http://dx.doi.org/10.4000/jso.451

Calvet-Mir, L., M. Calvet-Mir, J. L. Molina, and V. Reyes-García. 2012a. Seed exchange as an agrobiodiversity conservation mechanism. A case study in Vail Fosca, Catalan Pyrenees, Iberian Peninsula. Ecology and Society 17(1):29. http://dx.doi. org/10.5751/ES-04682-170129

Calvet-Mir, L., E. Gómez-Baggethun, and V. Reyes-García. 2012 $b$. Beyond food production: ecosystem services provided by home gardens. A case study in Vall Fosca, Catalan Pyrenees, Northeastern Spain. Ecological Economics 74:153-160. http://dx. doi.org/10.1016/i.ecolecon.2011.12.011

Chowning, A. 1979. Leadership in Melanesia. Journal of Pacific History 14(2):66-84. http://dx.doi.org/10.1080/00223347908572366

Conklin, H. C. 1974. An ethnoecological approach to shifting agriculture. Pages 167-172 in Y. A. Cohen, editor. Man in adaptation: the cultural present. Second edition. Aldine, Hawthorne, New York, USA.

Coomes, O. T., and N. Ban. 2004. Cultivated plant species diversity in home gardens of an Amazonian peasant village in northeastern Peru. Economic Botany 58(3):420-434. http://dx.doi. org/10.1663/0013-0001(2004)058[0420:cpsdih]2.0.co;2 
Coomes, O. T., S. J. McGuire, E. Garine, S. Caillon, D. McKey, E. Demeulenaere, D. Jarvis, G. Aistara, A. Barnaud, P. Clouvel, L. Emperaire, S. Louafi, P. Martin, F. Massol, M. Pautasso, C. Violon, and J. Wencélius. 2015. Farmer seed networks make a limited contribution to agriculture? Four common misconceptions. Food Policy 56:41-50. http://dx.doi.org/10.1016/j.foodpol.2015.07.008

Coupaye, L. 2009. Ways of enchanting: chaînes opératoires and yam cultivation in Nyamikum village, Maprik, Papua New Guinea. Journal of Material Culture 14(4):433-458. http://dx.doi. org/10.1177/1359183509345945

Csardi, G., and T. Nepusz. 2006. The igraph software package for complex network research. InterJournal Complex Systems 1695. [online] URL: http://www.interjournal.org/manuscript_abstract. php?361100992

Dark, P. J. C. 1974. Kilenge art and life: a look at a New Guinea people. Academy Editions, London, UK.

Davis, A., and J. R. Wagner. 2003. Who knows? On the importance of identifying "experts" when researching local ecological knowledge. Human Ecology 31(3):463-489. http://dx.doi. org/10.1023/A:1025075923297

de Coppet, D. 1981. The life-giving death. Pages 175-204 in S. C. Humphreys and H. King, editors. Mortality and immortality: the anthropology and archaeology of death. Academic Press, London, UK.

Demeulenaere, E., C. Bonneuil, F. Balfourier, A. Basson, J.-F. Berthellot, V. Chesneau, H. Ferté, N. Galic, G. Kastler, J. Koening, F. Mercier, J. Payement, A. Pommart, B. Ronot, Y. Rousselle, N. Supiot, H. Zaharia, and I. Goldringer. 2008. Étude des complémentarités entre gestion dynamique à la ferme et gestion statique en collection: cas de la variété de blé Rouge de Bordeaux. Les Actes du BRG 7:117-138.

Di Piazza, A. 1999. Migration d'une plante et migration de ses représentations. Le taro de marécage (Cyrtosperma chamissonis) sur Nikunau et Tabuaeran (République de Kiribati). Journal d'Agriculture Traditionnelle et de Botanique Appliquée 41 (1):93-108.

di Piazza, A., and D. Frimagacci. 1991. A thousand years of gardening: a history of subsistence on Futana. Bulletin of the Indo-Pacific Prehistory Association 11:124-141. [online] URL: http://journals.lib.washington.edu/index.php/BIPPA/article/ download/11378/10017

Domínguez, S., and B. Hollstein. 2014. Mixed methods social networks research: design and applications. Cambridge University Press, Cambridge, UK. http://dx.doi.org/10.1017/cbo9781139227193

Earle, T. 1980. Prehistoric irrigation in the Hawaiian Islands: an evaluation of evolutionary significance. Archaeology and Physical Anthropology in Oceania 15(1):1-28. http://dx.doi.org/10.1002/ j.1834-4453.1980.tb00316.x

Ellen, R. 1993. The cultural relations of classification: an analysis of Nuaulu animal categories from central Seram. Cambridge University Press, Cambridge, UK. http://dx.doi.org/10.1017/ $\underline{\mathrm{cbo} 9780511470530}$

Ellen, R. F. 2006. The categorical impulse: essays in the anthropology of classifying behaviour. Berghahn, New York, New York, USA.
Ellen, R., and S. Platten. 2011. The social life of seeds: the role of networks of relationships in the dispersal and cultural selection of plant germplasm. Journal of the Royal Anthropological Institute 17(3):563-584. http://dx.doi.org/10.1111/j.1467-9655.2011.01707. $\underline{x}$

Emperaire, L., and N. Peroni. 2007. Traditional management of agrobiodiversity in Brazil: a case study of manioc. Human Ecology 35(6):761-768. http://dx.doi.org/10.1007/s10745-007-9121$\underline{\mathrm{x}}$

Friedberg, C. 1986. Classifications populaires des plantes et modes de connaissance. Pages 21-49 in P. Tassay, editor. L'ordre et la diversité du vivant: quel statut scientifique pour les classifications biologiques. Fondation Diderot, Fayard, Paris, France.

Friedberg, C. 1992. Représentation, classification: comment l'homme pense ses relations au milieu naturel. Pages 357-371 in M. Jollivet, editor. Sciences de la nature, sciences de la société: les passeurs de frontières. CNRS Éditions, Paris, France.

Garine, E., A. Luxereau, J. Wencélius, C. Violon, T. Robert, A. Barnaud, S. Caillon, and C. Raimond. 2013. De qui les variétés traditionnelles de plantes cultivées pourraient-elles être le patrimoine? Réflexions depuis le Bassin du Lac Tchad. Pages 93-104 in D. Juhé-Beaulaton, M.-C. Cormier-Salem, P. de Robert, and B. Roussel, editors. Effervescence patrimoniale au Sud: enjeux, questions, limites. IRD Editions, Paris, France.

Godelier, M. 1996. L'Enigme du don. Fayard, Paris, France.

Gouldner, A. W. 1960. The norm of reciprocity: a preliminary statement. American Sociological Review 25(2):161-178. http://dx. doi.org/10.2307/2092623

Haudricourt, A. G. 1964. Nature et culture dans la civilisation de l'igname: l'origine des clones et des clans. L'Homme 4(1):93-104. http://dx.doi.org/10.3406/hom.1964.366613

Heckler, S. L. 2004. Tedium and creativity: the valorization of manioc cultivation and Piaroa women. Journal of the Royal Anthropological Institute 10(2):241-259. http://dx.doi.org/10.1111/ j.1467-9655.2004.00188.x

Heckler, S., and S. Zent. 2008. Piaroa manioc varietals: hyperdiversity or social currency? Human Ecology 36(5):679-697. http://dx.doi.org/10.1007/s10745-008-9193-2

Hodgkin, T., R. Rana, J. Tuxill, D. Balma, A. Subedi, I. Mar, D. Karamura, R. Valdivia, L. Collado, L. Latournerie, M. Sadiki, M. Sawadogo, A. H. D. Brown, and D. I. Jarvis. 2007. Seed systems and crop genetic diversity in agroecosystems. Pages 77-116 in D. I. Jarvis, C. Padoch, and H. D. Cooper, editors. Managing biodiversity in agricultural ecosystems. Columbia University Press, New York, New York, USA.

Huitsing, G., M. A. J. van Duijn, T. A. B. Snijders, P. Wang, M. Sainio, C. Salmivalli, and R. Veenstra. 2012. Univariate and multivariate models of positive and negative networks: liking, disliking, and bully-victim relationships. Social Networks 34 (4):645-657. http://dx.doi.org/10.1016/j.socnet.2012.08.001

Hunn, E. 1982. The utilitarian factor in folk biological classification. American Anthropologist 84(4):830-847. http://dx. doi.org/10.1525/aa.1982.84.4.02a00070 
Isaac, M. E. 2012. Agricultural information exchange and organizational ties: the effect of network topology on managing agrodiversity. Agricultural Systems 109:9-15. http://dx.doi. org/10.1016/j.agsy.2012.01.011

Isaac, M. E., B. H. Erickson, S. J. Quashie-Sam, and V. R. Timmer. 2007. Transfer of knowledge on agroforestry management practices: the structure of farmer advice networks. Ecology and Society 12(2):32. [online] URL: http://www.ecologyandsociety. org/vol12/iss $2 / \operatorname{art} 32 /$

Jarvis, D. I., T. Hodgkin, B. R. Sthapit, C. Fadda, and I. LopezNoriega. 2011. An heuristic framework for identifying multiple ways of supporting the conservation and use of traditional crop varieties within the agricultural production system. Critical Reviews in Plant Science 30(1-2):125-176. http://dx.doi. org/10.1080/07352689.2011.554358

Kawa, N. C., C. McCarty, and C. R. Clement. 2013. Manioc varietal diversity, social networks, and distribution constraints in rural Amazonia. Current Anthropology 54(6):764-770. http://dx. doi.org/10.1086/673528

Koskinen, J., and T. A. B. Snijders. 2012. Simulation, estimation, and goodness of fit. Pages 141-166 in D. Lusher, J. Koskinen, and G. Robins, editors. Exponential random graph models for social networks: theory, methods, and applications. Cambridge University Press, Cambridge, UK. http://dx.doi.org/10.1017/ $\underline{\text { cbo9780511894701.014 }}$

Lazega, E., L. Mounier, T. Snijders, and P. Tubaro. 2012. Norms, status and the dynamics of advice networks: a case study. Social Networks 34(3):323-332. http://dx.doi.org/10.1016/j.socnet.2009.12.001

Leclerc, C., and G. Coppens d'Eeckenbrugge. 2012. Social organization of crop genetic diversity. The $\mathrm{G} \times \mathrm{E} \times \mathrm{S}$ interaction model. Diversity 4(1):1-32. http://dx.doi.org/10.3390/d4010001

Lemonnier, P. 1982. Les jardins Anga (Nouvelle-Guinée). Journal d'Agriculture Traditionnelle et de Botanique Appliquée 29 (3):228-245. http://dx.doi.org/10.3406/jatba.1982.3874

Lepowsky, M. 1990. Big men, big women, and cultural autonomy. Ethnology 29(1):35-50. http://dx.doi.org/10.2307/3773480

Lindstrom, L. 1990. Knowledge and power in a South Pacific society. Smithsonian Institution Press, Washington, D.C., USA.

Lutkehaus, N. C., and P. B. Roscoe, editors. 1995. Gender rituals: female initiation in Melanesia. Routledge, London, UK.

Malinowski, B. 1922. Les argonautes du Pacifique occidental. (A. Devyver and S. Devyver, translators). Gallimard, Paris, France.

Malinowski, B. 1929. The sexual life of savages in north-western Melanesia: an ethnographic account of courtship, marriage and family life among the natives of the Trobriand islands, British New Guinea. Routledge, London, UK.

Mauss, M. 1925. Essai sur le don: forme et raison de l'échange dans les sociétés archaïques. L'année sociologique série 2. Les Presses universitaires de France, Paris, France. http://dx.doi.org/10.1522/ cla.mam.ess 3

McGuire, S. J. 2008. Securing access to seed: social relations and sorghum seed exchange in eastern Ethiopia. Human Ecology 36 (2):217-229. http://dx.doi.org/10.1007/s10745-007-9143-4
Meilleur, B. A. 1998. Clones within clones: cosmology and esthetics and Polynesian crop selection. Anthropologica 40 (1):71-82. http://dx.doi.org/10.2307/25605873

Meinzen-Dick, R., and P. Eyzaguirre. 2009. Non-market institutions for agrobiodiversity conservation. Pages 82-91 in A. Kontoleon, U. Pascual, and M. Smale, editors. Agrobiodiversity conservation and economic development. Routledge, London, $\mathrm{UK}$.

Monnerie, D. 2012. Objets cérémoniels, chaînes opératoires et élaboration des relations sociales (arama et hoot ma whaap, kanaky Nouvelle-Calédonie, Mélanésie). Techniques and Culture 58:122-141. http://dx.doi.org/10.4000/tc.6497

Monnerie, D. 2014. Les échanges en Océanie et l'anthropologie. Pages 127-160 in L. Dousset, B. Glowczewski, and M. Salaün, editors. Les sciences humaines et sociales dans le pacifique Sud. Terrains, questions et méthodes. Pacific-Credo Publications, Marseille, France.

Muller, S. 2009. Les plantes à tubercules, au cœur de la redéfinition des territoires et de l'identité au Vanuatu (Mélanésie). Autrepart 50(2):167-186.

Muller, S., V. Lebot, and A. Walter. 2010. Food-garden biodiversity in Vanuatu. Pages 508-514 in P. Bouchet, H. Le Guyader, and O. Pascal, editors. The natural history of Santo. Muséum National d'Histoire Naturelle, Paris, France.

Pautasso, M., G. Aistara, A. Barnaud, S. Caillon, P. Clouvel, O. T. Coomes, M. Delêtre, E. Demeulenaere, P. De Santis, T. Döring, L. Eloy, L. Emperaire, E. Garine, I. Goldringer, D. Jarvis, H. I. Joly, C. Leclerc, S. Louafi, P. Martin, F. Massol, S. McGuire, D. McKey, C. Padoch, C. Soler, M. Thomas, and S. Tramontini. 2013. Seed exchange networks for agrobiodiversity conservation. A review. Agronomy for Sustainable Development 33(1):151-175. http://dx.doi.org/10.1007/s13593-012-0089-6

Perrault-Archambault, M., and O. T. Coomes. 2008. Distribution of agrobiodiversity in home gardens along the Corrientes River, Peruvian Amazon. Economic Botany 62(2):109. http://dx.doi. org/10.1007/s12231-008-9010-2

Pollock, N. J. 1992. The roots remain: food habits in islands of the central and eastern Pacific since Western contact. Institute for Polynesian Studies, University of Hawaii Press, Honolulu, Hawaii, USA.

Poudel, D., B. Sthapit, and P. Shrestha. 2015. An analysis of social seed network and its contribution to on-farm conservation of crop genetic diversity in Nepal. International Journal of Biodiversity 2015:e312621. http://dx.doi.org/10.1155/2015/312621

R Core Team. 2014. R: a language and environment for statistical computing. R Foundation for Statistical Computing, Vienna, Austria.

Reyes-García, V., J. L. Molina, L. Calvet-Mir, L. Aceituno-Mata, J. J. Lastra, R. Ontillera, M. Parada, M. Pardo-de-Santayana, M. Rigat, J. Vallès, and T. Garnatje. 2013. "Tertius gaudens": germplasm exchange networks and agroecological knowledge among home gardeners in the Iberian Peninsula. Journal of Ethnobiology and Ethnomedicine 9:53. http://dx.doi. org/10.1186/1746-4269-9-53 
Ricciardi, V. 2015. Social seed networks: identifying central farmers for equitable seed access. Agricultural Systems 139:110-121. http://dx.doi.org/10.1016/j.agsy.2015.07.002

Robins, G., T. Snijders, P. Wang, M. Handcock, and P. Pattison. 2007. Recent developments in exponential random graph $\left(p^{*}\right)$ models for social networks. Social Networks 29(2):192-215. http:// dx.doi.org/10.1016/j.socnet.2006.08.003

Sahlins, M. 1965. On the sociology of primitive exchange. Pages 139-227 in M. Gluckman and F. Eggan, editors. The relevance of models for social anthropology. Tavistock Publications, London, UK.

Smale, M., and M. R. Bellon. 1999. A conceptual framework for valuing on-farm genetic resources. Pages 387-408 in D. Wood and J. M. Lenné, editors. Agrobiodiversity: characterization, utilization and management. CABI Publishing, Wallingford, UK.

Snijders, T. A. B., P. E. Pattison, G. L. Robins, and M. S. Handcock. 2006. New specifications for exponential random graph models. Sociological Methodology 36(1):99-153. http://dx. doi.org/10.1111/j.1467-9531.2006.00176.x

Sorokin, P. A. 1927. Social mobility. Harper and Row, New York, New York, USA.

Stern, M. 2013. Music in traditional exchanges in north Vanuatu. Pacific Studies 36(1-2):59-76. [online] URL: https://ojs.lib.byu. edu/spc/index.php/PacificStudies/article/view/35207/32997

Subedi, A., D. Singh, P. Shrestha, S. R. Subedi, and B. R. Sthapit. 2005. Stability of farmers' networks and nodal farmers in terai and hill villages of Nepal: implications for agrobiodiversity management on-farm. Page 36-40 in B. R. Sthapit, M. P. Upadhyay, P. K. Shrestha, and D. I. Jarvis, editors. On-farm conservation of agricultural biodiversity in Nepal. Volume II. Managing diversity and promoting its benefits. International Plant Genetic Resources Institute, Rome, Italy.

Thomas, M., J. C. Dawson, I. Goldringer, and C. Bonneuil. 2011. Seed exchanges, a key to analyze crop diversity dynamics in farmer-led on-farm conservation. Genetic Resources and Crop Evolution 58(3):321-338. http://dx.doi.org/10.1007/s10722-011-9662-0

Thurnwald, R. 1916. Bánaro society; social organization and kinship system of a tribe in the interior of New Guinea. Memoirs of the American Anthropological Association 3(4):251-412.

VNSO (Vanuatu National Statistics Office). 2009. 2009 census tables. Vanuatu National Statistics Office, Port Vila, Vanuatu.

Wang, P., G. L. Robins, and P. E. Pattison. 2009. PNet: program for the simulation and estimation of exponential random graph $\left(p^{*}\right)$ models: user manual. University of Melbourne, Melbourne, Australia. [online] URL: http://www.swinburne.edu.au/fbl/ research/transformative-innovation/our-research/MelNet-socialnetwork-group/PNet-software/resources/PNetManual.pdf

Weiner, A. B. 1992. Inalienable possessions: the paradox of keeping-while-giving. University of California Press, Berkeley, California, USA. http://dx.doi.org/10.1525/california/97805200$\underline{76037.001 .0001}$ 